\title{
INDIVIDUALISM AND COLLECTIVISM IN THE FOUNDATION OF GROUP RIGHTS
}

\author{
INDIVIDUALISMO E COLETIVISMO NA FUNDAÇÃO DOS DIREITOS DE GRUPO
}

\author{
Stephan Kirste \\ Doctor Iuris \\ Universidade de Salzburgo, Austria \\ stephan.kirste@sbg.ac.at
}

\begin{abstract}
This study examines the question of whether group rights are human rights. The question of whether group rights are human rights is not as harmless and formal as it seems at first. If human rights were only rights of individual human beings and collective rights were only rights of groups, then they would belong to substantially different categories of rights. In addition, group rights could not be based on human dignity. In this article, I intend to show that group rights are in fact a form of human rights. However, neither the individualist nor the collectivist approach can justify this claim. We have to find an attribute common to individuals and groups, which at the same time can be an element of human rights.
\end{abstract}

Keywords: Human Rights. Group rights. International Law.

Resumo: Examina-se a questão de saber se os direitos de grupo são Direitos Humanos. A questão de saber se os direitos de grupo são Direitos Humanos não é tão inofensiva e formal como parece à primeira vista. Se os Direitos Humanos fossem apenas direitos de seres humanos individuais e os direitos coletivos fossem apenas direitos de grupos, então eles pertenceriam a categorias de direitos substancialmente diferentes. Além disso, os direitos de grupo não poderiam ser baseados na dignidade humana. Neste artigo, pretende-se demonstrar que os direitos de grupo são de fato uma forma de Direitos Humanos. No entanto, nem a abordagem individualista nem a coletivista podem justificar essa afirmação. Há necessidade de encontrar um atributo comum a indivíduos e grupos, que possa ao mesmo tempo ser um elemento dos Direitos Humanos.

Palavras-chave: Direitos Humanos. Direitos de Grupo. Direito Internacional.

\section{Para citar este artigo}

ABNT NBR 6023:2018

KIRSTE, Stephan. Individualism and collectivism in the foundation of group rights. Prisma Jurídico, São Paulo, v. 19, n. 2, p. 347-367, jul./dez. 2020. http://doi.org/10.5585/prismaj.v19n2.18721. 


\section{Introduction}

Are group rights human rights? This question is analyzed in the present paper. The question is triggered by remarks such as the one by James Griffin at the end of his book "On Human Rights”: „Are we not better off without the third generation of rights?“1 In the book Griffin holds that human rights conceived as rights of groups are ill-founded. To avoid semantic ambiguities and a devaluation of the concept of human rights, group rights should not count as human rights, or so he argues.

A theory of human rights that does not postulate a concept of human rights a priori, but intends to reconstruct existing human rights based on philosophical principles instead, will probably not follow this criticism, because there are rights in international treaties called "group rights". For this reason Robert Alexy does not preclude the possibility of a foundation of group rights; but he wants to avoid ambiguities on a conceptual level and does not call these rights "human rights". Among the five necessary distinguishing elements of human rights and other rights is universality. Only human beings as individuals would universally possess human rights. The so called "third generation rights" would therefore not fall under the term "human right". ${ }^{2}$ For the sake of clarity, he calls them "communal rights" or "rights of states".

Others emphasize that, in their negative dimension, human rights are rights against groups and that it would therefore be self-contradictory if these groups themselves would bear human rights. ${ }^{3}$ Group rights as rights of minorities could, for example, only be justified on a secondary level of fundamental rights in constitutions. ${ }^{4}$

Against this skepticism, some authors like the Serbian constitutional scholar Miodrag Jovanovic claim that, from a standpoint of "value collectivism", group rights would form a sufficiently distinguishable class of human rights. One of the assumptions justifying this thesis is that collective rights need not necessarily match human rights. In hard cases, they could even set them off, which would show that they could be justified independently. ${ }^{5}$

The question if group rights are human rights is not as harmless and formal as it appears at first glance. If human rights are only rights of individual human beings and collective rights

\footnotetext{
${ }^{1}$ Griffin 2011, p. 276: ,After the combined workings of exclusion and reduction, are there any compelling examples left in the class of moral group rights? When putative moral group rights seem to have the status of rights, is it not because they are reducible to human rights? Can we attach sufficiently clear criteria to the term 'group rights' to make it a helpful, non-redundant addition to our moral vocabulary".

2 Alexy 1998, p. 247.

${ }^{3}$ Donnelly 1985, p. 497; Lohmann 2013, p. 148: Menschenrechte „sind Rechte, die der individuelle Rechtsträger notfalls auch gegen die Gemeinschaften durchsetzen kann, denen er angehört, sogar gegen den Staat, in dessen Rechtsordnung seine Menschenrechte als Grundrechte ggf. verfasst sind. Plakativ gesprochen: die Menschenrechte schützen den Einzelnen, und nicht Gemeinschaften!“”.

${ }^{4}$ Lohmann 2013, p. 158.

${ }^{5}$ From the standpoint of a ,value collectivism, which entails that collective rights need not always be in accordance with individual rights. Quite the contrary, they can at times override even some of individual rights that might qualify for the status of universal human rights", Jovanovic 2012, p. 189.
} 
are only rights of groups, then they would belong to substantially different categories of rights. In addition, group rights could not be based on human dignity. ${ }^{6}$ We would then have to determine the relation of the two: What is their embracing concept? If both are individual rights, are group rights claims of minor importance, both in form and in content? The attempt to found group rights on collective values of these groups would not overcome this dualism, because these values would differ in kind from the individual-related values grounding human rights. Group rights would also still have a subject different from human rights. A solution to this difficulty could be to conceptualize group rights as rights deduced from the rights of the members of the respective group. In their deduced form, they would still be indebted to their fundament in individual human rights. However, such a justification could neither be based on the notion of collective values as a basis of these rights, nor does it take into account the difficulty of a collision of individual and group rights.

In this paper, I intend to show that group rights are indeed a form of human rights. However, neither the individualist nor the collectivist approaches can justify this claim. We have to find an attribute common to individuals and groups, which at the same time can be an element of human rights. What distinguishes them from individual human rights is that they legally relate to features that men have exclusively with regard to their belonging to a certain group. They are still universal in the sense that all men, would they be member of such a group, would have the respective right. Group rights express the social relation of all human beings. They protect the group related features of men and the very groups realizing them. Whereas the groups of collective rights share with legal persons the formal quality that they are subjects of rights, they are distinguished by the purpose of these rights: Legal persons in have rights that serve the interest of the collective person as such independently of their members - if they have members at all. Group rights are rights attributed to groups because of the group life of their members; they are attributed to individuals because of their social life in these groups or as negative rights against the state, protecting them against discrimination or infringement of their group life or of their status as member of the broader political community, such as the state.

\section{Group rights in international law}

As human rights developed from individual negative rights against public authority to positive claims to public subsidies, it became apparent that men need protection also in their

${ }^{6}$ Human dignity is the fundament of human rights, Kirste 2013, p. 119. 
social life, namely in their communicative and political activities. ${ }^{7}$ Especially as minorities, these groups are just as endangered as is the individual itself. They deserve protection in their religious, cultural, political lives, in their languages and their traditions. A precondition for these forms of social and cultural life is a certain independence of a group - be it a minority or a nation - from others. It meant a first step in acknowledging this that - inspired by the Fourteen Points of Woodrow Wilson - the right to self-determination of people was protected in Art. 1 II of the Charter of the United Nations. Legal subject of this right is a people as a collective.

\subsection{The Right to Self-Determination}

The oldest group right is the right to self-determination of peoples. More than others does this right seem to show distinctive aspects of rights of groups qua group. Art. 1 of the ICCPR and Art. 1 of the ICESR reads: "Article 1. 1. All peoples have the right of selfdetermination. By virtue of that right they freely determine their political status and freely pursue their economic, social and cultural development".

Does this right really make peoples subjects of law $?^{8}$ Some scholars assume that peoples would have a "legal status without individual rights". 9 The de-colonial right to selfdetermination of peoples has been the door opener for the modern right to self-determination. Woodrow Wilson demanded the recognition of such a right despite its ambivalences and risks. In his conception, the right was limited though and it should not be used to put a threat on peace. Originally, the debate concentrated mostly on the external self-determination. Up until today, however, it is unclear whether the right includes a right to secession. ${ }^{10}$

The factual and legal conditions of the right to self-determination of peoples have changed since Wilson's time. It became apparent that there is a tension between this right and peace, because it could ultimately lead to a removal and new establishment of territorial borders. The recognition of individual human rights after World War II in particular lead to a new understanding of the right to self-determination of peoples. ${ }^{11}$ As early as 1960, a declaration of the UN General Assembly formulated: “All peoples have the right to self-determination; by

\footnotetext{
${ }^{7}$ Cf. Kirste 2013a, pp. $103 \mathrm{ff}$.

${ }^{8}$ Heilbronner/Kau 2010, marginal no. $32 \mathrm{f}$.

${ }^{9}$ Heilbronner/Kau marginal no. 33 .

${ }^{10}$ Heilbronner/Kau marginal no. $124 \mathrm{f}$. refusing.

${ }^{11}$ Hilpold 2013, p. 1081: „Die Gesamtrechtsstruktur der Selbstbestimmungsforderungen, die im Europa des 21. Jahrhunderts erhoben werden, unterscheidet sich wesentlich von jener der Geburtsstunde des modernen Selbstbestimmungsrechts (1918), als Europa eine Neuordnung erfahren sollte. Die aktuellen Forderungen nach Selbstbestimmung fügen sich ein in ein System stark verdichteter Grundrechte, denen prioritäre Bedeutung beizumessen ist. Insgesamt hat sich eine weitgehende Abwendung von der Gruppe als Schutzadressatin und eine Zuwendung zum Individuum vollzogen... die Gruppenbezogenheit. hat nur instrumentalen Charakter; um letztlich dem Individuum einen noch effektiveren Schutz angedeihen zu lassen“.
} 
virtue of that right they freely determine their political status and freely pursue their economic, social and cultural development". ${ }^{12}$

Clearly, subject of this right is the group as such. The principle influenced the 1966 pacts and overcame the context of de-colonization. ${ }^{13}$ "The establishment of a sovereign and independent State, the free association or integration, with an independent State or the emergence into any other political status freely determined by a people constitutes modes of implementing the right of self-determination by that people." 14

The focus of protection shifted accordingly, from the external right to self-determination towards autonomy and self-government as core elements of self-determination. The right to self-determination is the right of a group to decide about their political status as part of their self-government. The internal self-determination thereby becomes a precondition for the external. Nowadays, many efforts are made to avoid external self-determination and secession by granting peoples more internal self-determination in the form of self-government. ${ }^{15}$ Status of autonomy or devolution can strengthen the internal identity forming and realizing processes in a way that at the same time improves the rights of the members of these groups to participate in the formation of the group. ${ }^{16}$ Thereby self-determination can be reconstructed from individual human rights.

In this way, the internal self-determination gains its significance by legitimizing public authorities also through minorities. ${ }^{17}$ Democracy requires the legitimation of government by the governed. This again generally calls for the consent of all subjects of public authority. The majority principle fulfills this requirement, if understood as a temporalized co-decision process of all. If structural minorities develop that are excluded from the democratic self-determination, because they can never achieve a majority, other forms of the realization of democracy are needed. Otherwise, the main idea of democracy would be spoiled. Here the right to selfdetermination comes in. It secures the freedom of the minority: ${ }^{18}$ democracy guarantees the freedom of the majority; self-determination guarantees the freedom of the minority. Both contribute to unanimity. ${ }^{19}$

\footnotetext{
${ }^{12}$ UN-GV Res. 1514 (XV) from Dec. $14^{\text {th }} 1960$, Declaration on the granting of independence to colonial countries and peoples, No. 2.

${ }^{13}$ Boysen 2009, p. 436.

${ }^{14} \mathrm{UN}-\mathrm{GV}$ Res. 2625 (XXV) of 24th of Oct. 1970

${ }^{15}$ Hilpold 2013, p. 1082.

${ }^{16}$ Kirste 2012 a, marginal no. 6 f. 14 u. 38.

${ }^{17}$ Hilpold 2013, p. 1085: Unter dem internen Recht auf Selbstbestimmung, ,versteht man die umfassende Einbindung der Minderheiten in den demokratischen Entscheidungsprozess, wodurch ihre kulturelle Identität gewahrt werden kann, eine Diskriminierung von Minderheiten verhindert und ihre gleichberechtigte Entwicklung neben .der Mehrheitsbevölkerung sichergestellt werden ·kann“.

${ }^{18}$ Rainer 1961, p. 461.

${ }^{19}$ Rainer 1961, p. 487.
} 


\title{
1.2 Minority Rights
}

Art. 27 of the Universal declaration acknowledges the social dimension of the individual and protects his participation "in the cultural life of the community". Clearly, the individual human being is subject of this right and not a group. However, he has this right with regard to a group, a certain cultural community. The mutuality between individual and community is expressed in Art. 29 UDHR, which emphasizes that, apart from rights, the individual also has duties towards the community "in which alone the free and full development of his personality is possible". Accordingly, although there are responsibilities of the individual towards the group, these rights are dependent upon the structure of this group as furthering his development and personality.

In 1981 the African Charter on Human and Peoples' Rights was the first declaration to introduce a right to development into the international human rights discourse as both a collective and individual right in Art. 2 and 22. ${ }^{20}$ Although the charter distinguishes "Human Rights" and "Peoples' Rights", it emphasizes

\begin{abstract}
on the one hand, that fundamental human rights stem from the attributes of human beings which justifies their national and international protection and on the other hand that the reality and respect of peoples rights should necessarily guarantee human rights.
\end{abstract}

The Charter thereby acknowledges a mutual dependency of the development of the individual and the group, by relating respective rights to express opinions (Art. 9), associate (Art. 10) and assemble (Art. 11), access to public service and property (Art. 13) and the right to education. It also recognizes that the individual "may freely, take part in the cultural life of his community" (Art. 17) and also speaks of the "duties towards ... family and society, the State and other legally recognized communities and the international community" (Art. 27). The Charter especially mentions respect to others (Art. 28) and the duty "to preserve the harmonious development of the family" (Art. 29) ${ }^{21}$. Peoples themselves have "the right to their economic, social and cultural development with due regard to their freedom and identity and in the equal enjoyment of the common heritage of mankind" (Art. 22).

\footnotetext{
${ }^{20}$ African [Banjul] Charter on Human and Peoples' Rights, adopted June 27, 1981, OAU Doc. CAB/LEG/67/3 rev. 5, 21 I.L.M. 58 (1982): „Article 22: 1. All peoples shall have the right to their economic, social and cultural development with due regard to their freedom and identity and in the equal enjoyment of the common heritage of mankind. 2. States shall have the duty, individually or collectively, to ensure the exercise of the right to development".

${ }^{21}$ And also the duty 7. "to preserve and strengthen positive African cultural values in his relations with other members of the society, in the spirit of tolerance, dialogue and consultation and, in general, to contribute to the promotion of the moral well being of society".
} 
On the universal level, the UN General Assembly proclaimed this right in the "Declaration on the Right to Development" as a individual and collective claim in $1986 .{ }^{22}$ It recalled the international strive for the decolonization, the right to self-determination, sovereignty over natural wealth and resources of peoples, but also asks to keep in mind the respect for individual rights towards groups and peoples in the preamble. In its introduction, it also considers the infringement of the previously recognized human rights as a major obstacle of the fulfillment of both human beings and peoples. The declaration explicitly states "that the human person is the central subject of the development process and that development policy should therefore make the human being the main participant and beneficiary of development" (Preamble). This is the basis to secure in Art. 1:

1. The right to development is an inalienable human right by virtue of which every human person and all peoples are entitled to participate in, contribute to, and enjoy economic, social, cultural and political development, in which all human rights and fundamental freedoms can be fully realized.

Art. 2 repeats that "the human person is the central subject of development and should be the active participant and beneficiary/bearer of the right to development". States are the responsible subject for the furthering and realization of this right towards both individuals and peoples. They fulfill these obligations by securing negative, positive and active rights of individuals and groups. The use of the right to development is limited by the human rights of the Universal Declaration and other international human rights covenants. Taken together it contains both individual and collective rights of peoples, although the declaration emphasizes the individual basis of collective rights more clearly.

The central position of the individual, even in declarations containing collective rights, was confirmed in the 1993 Vienna Declaration and Program of Action. This declaration connects the right to development to the democratization of the developing countries (I.9.) ${ }^{23}$. It further reminds these countries of their responsibilities for the realization of human rights. Only then refers it to the collective rights to self-determination and development. In this development "the human person is the central subject of development" (I.10): "lack of development may not be invoked to justify the abridgement of internationally recognized human rights". In Nr. 20 the Vienna Declaration recognizes "the inherent dignity and unique contribution of indigenous people", a state responsibility to their protection, participation and calls for the security of

\footnotetext{
${ }^{22}$ Resolution $41 / 128$

${ }^{23}$ I.8: ,Democracy, development and respect for human rights and fundamental freedoms are interdependent and mutually reinforcing. Democracy is based on the freely expressed will of the people to determine their own political, economic, social and cultural system and their full participation in all aspects of their lives".
} 
fundamental rights of indigenous people. "Persons belonging to groups which have been rendered vulnerable" need special protection (I.24). Taken together, the Vienna Declaration strengthens the mutual relation of individual and group (indigenous rights), though it gives prevalence to the individual rights.

In 1992 the United Nations "Conference on Environment and Development" in Rio established 27 principles to guide a future sustainable development, at the top of which the human individual is positioned. ${ }^{24}$ Groups are mentioned (Principle 22), not as subjects of rights, but only as the matter of the duty of states to protect them (also principle 23) and in their role for the environment.

The Declaration of the Rights of Indigenous Peoples mentions the "right to development" of peoples in the preamble and in the text of the declaration. ${ }^{25}$ These rights are derived both from contracts of these peoples with states and from their spiritual traditions, histories, philosophies, rights to their lands and their political, economic and social structures. ${ }^{26}$ These are clearly common goods of the respective people, not to be individually consumed. Indigenous people contribute with their traditional knowledge, techniques, medicine to the world community as a whole. This may be the reason, why the declaration even goes so far as to speak of a "dignity ... of the indigenous peoples" (Art. 43). The declaration also mentions the interrelation of individual human rights of indigenous individuals and groups. ${ }^{27}$ It is remarkable though that the declaration recognizes a couple of rights of the indigenous peoples as groups, like equality with respect to other peoples (Art. 2), self-determination (Art. 3) ${ }^{28}$ development of their cultural heritage (Art. 31) etc. and distinguish them from the rights of indigenous individuals (Art. 6 ff.). Both, individuals and groups can obtain other rights. The exercise of these rights, however, may not infringe individual human rights (Art. 46). Despite this limitation by individual rights, it is quite apparent that the Declaration emphasizes group rights more explicitly than previous rights. It contains rights, the benefitted subjects/rightholder of which are individuals and groups; the obliged subjects are groups and states.

On the regional level, the Framework-Convention of the Council of Europe for the Protection of National Minorities from 1995 deserves to be mentioned. In Article 1 the

\footnotetext{
${ }^{24}$ A/Conf.151/26, 12th of August 1992, "Principle 1 Human beings are at the centre of concerns for sustainable development".

${ }^{25}$ Resolution 61/295 by the UN-General Assembly of Sept. $13^{\text {th }} 2007$.

${ }^{26}$ Preamble of the Resolution 61/295.

${ }^{27}$ Preamble: „Recognizing and reaffirming that indigenous individuals are entitled without discrimination to all human rights recognized in international law, and that indigenous peoples possess collective rights which are indispensable for their existence, well-being and integral development as peoples". And then Art. 1: "Indigenous peoples have the right to the full enjoyment, as a collective or as individuals, of all human rights and fundamental freedoms as recognized in the Charter of the United Nations, the Universal Declaration of Human Rights4 and international human rights law".

28 ,Indigenous peoples have the right to self-determination. By virtue of that right they freely determine their political status and freely pursue their economic, social and cultural development".
} 
Conventions clearly considers rights of national minorities and rights of persons within these groups as human rights. ${ }^{29}$ The Convention not only protects the rights of minorities, but also of individuals with respect to these minorities. ${ }^{30}$ However, at the center of the declaration stand "persons belonging to national minorities", not the minority itself. ${ }^{31}$ The report emphasizes the role of the convention as the first "legally binding multilateral instrument devoted to the protection of national minorities in general" (No. 10). However, the Convention contains only programs, which are not directly applicable, and does not itself proclaim any rights (No 11). "It does not imply the recognition of collective rights“ (No. 13). However, it recognizes the idea that minorities as well as members of minorities can have rights and considers itself an addition to existing minority rights protections. ${ }^{32}$ It refrains from establishing individual or collective rights, because the situations of minorities differ greatly between countries. ${ }^{33}$ The 1998 Charter for Regional or Minority Languages again is aware of collective rights (Preamble), but does not proclaim such rights itself. ${ }^{34}$ The report to the Charter explains this through the Charter's focus on the objective cultural function of language rather than on the speakers or the minorities speaking a language. ${ }^{35}$ So the overall goal is to protect languages as values in themselves rather than subjects, be they collective or individual.

Taken together, these declarations grant individuals belonging to groups certain rights towards the group and towards the state because of their membership in these groups. Some of them also include rights of groups themselves, be they minorities or nations. None of these declarations excludes the possibility that groups are subjects of human rights. Even declarations, which do not include rights at all or concentrate on individual rights, presuppose collective rights of groups. Accordingly, one is entitled to assume that the rights to existence ${ }^{36}$, self-determination, development, peace, protection of the environment and to the participation

\footnotetext{
${ }^{29}$ Framework Convention for the Protection of National Minorities H (95), 10, of Feb. 1995: “Article 1: The protection of national minorities and of the rights and freedoms of persons belonging to those minorities forms an integral part of the international protection of human rights, and as such falls within the scope of international co-operation".

${ }^{30}$ Article 3: „Every person belonging to a national minority shall have the right freely to choose to be treated or not to be treated as such and no disadvantage shall result from this choice or from the exercise of the rights which are connected to that choice".

${ }^{31}$ Report No 31: ,The article refers to the protection of national minorities as such and of the rights and freedoms of persons belonging to such minorities. This distinction and the difference in wording make it clear that no collective rights of national minorities are envisaged (see also the commentary to Article 3). The Parties do however recognise that protection of a national minority can be achieved through protection of the rights of individuals belonging to such a minority".

${ }^{32}$ Pamphlet to the Convention, p. 2.

${ }^{33}$ Cf. the Pamphlet to the Convention, p. 2.

${ }^{34}$ Explanatory Report, Nr. 11: ,The charter does not establish any individual or collective rights for the speakers of regional or minority languages".

${ }^{35}$ Explanatory Report, Nr. 17: „The concept of language as used in the charter focuses primarily on the cultural function of language. That is why it is not defined subjectively in such a way as to consecrate an individual right, that is the right to speak "one's own language", it being left to each individual to define that language. Nor is reliance placed on a politico-social or ethnic definition by describing a language as the vehicle of a particular social or ethnic group. Consequently, the charter is able to refrain from defining the concept of linguistic minorities, since its aim is not to stipulate the rights of ethnic and/or cultural minority groups, but to protect and promote regional or minority languages as such".

${ }^{36} \mathrm{Cf}$. Article 43 DRIPS

"The rights recognized herein constitute the minimum standards for the survival, dignity and well-being of the indigenous peoples of the world".
} 
in the common heritage of humankind have a collective dimension. ${ }^{37}$ Other individual rights are established on behalf of the individual person, with respect to its membership in a group against discrimination.

\section{Conceptions, justifications and critique of group rights}

\subsection{Conceptions of Group Rights}

The field of claims commonly called "group rights" is very heterogeneous. They are all group related, but some have groups as their benefitted subjects/right-holders, others individuals as members of groups - among them some with groups as the obligated subject-, and others states with respect of their membership. Only the first would be collective rights, because collective rights - justified or not - would be rights the beneficiary of which are groups.

Part of the literature assumes that group rights are exclusively collective rights. Winfried Brugger holds that group rights are only rights of "peoples or states themselves", attributed to them "for the benefit of the individual members represented by them". ${ }^{38}$ In addition, Peter Jones claims that group rights are only rights of a group qua group. Accordingly, individual rights of members of groups are not group rights, even if such a right is based on the criterion of membership. ${ }^{39}$ Michael Freeman specifies that group rights are "irreducible to individual rights", but compatible with them. ${ }^{40}$ Miodrag Jovanovic omits this qualifying criterion. $\mathrm{He}$ holds that there are rights that have a collective nature. Helmut Rittsteig finally assumes that group rights mean that to a certain amount a minority has legal personality and an organization as such. ${ }^{41}$ The result of all these opinions would be a precise, albeit very limited, concept of group rights that would encompass only the collective rights of the above mentioned declarations.

Others have a broader conception of group rights. Thomas Pogge for example holds that the right of a Sikh to drive a bike without helmet would be a group right, because it is group related. ${ }^{4243}$ Another example would be Art. 11, 2 of the European Framework Convention: "The

\footnotetext{
${ }^{37}$ Weiß 2012, p. 228.

${ }^{38}$ Brugger 1999, p. 76.

${ }^{39}$ Jones 1999, p. 354: „There is little about group rights that is uncontroversial but there is at least this much agreement upon the basic concept: a right is a group right only if it is a right held by a group rather than by its members separately. If rights are held by individuals separately, their shared rights do not add up to a group right even though their rights relate to a characteristic which marks them off, sociologically, as a group. A right is a group right only if it is a right held by a group qua group".

${ }^{40}$ Freeman 1995 , p. 38 : collective rights would be rights,

„the bearers of which are collectives, which are not reducible to, but are consistent with individual rights, and the basic justification of which is the same as the basic justification of individual rights"”.

${ }^{41}$ Rittsteig 1996, p. 1004: Group rights ,,bedeuten, daß die Minderheit zu einem gewissen Maß Rechtspersönlichkeit erlangt und als solche eine Organisation erhält".

${ }^{42}$ Sentence 32 (2a) des Road Traffic Acts 1972: „A requirement imposed by regulations under this section ... shall not apply to any follower of the Sikh religion while he is wearing a turban".

${ }^{43}$ Pogge 1997, p. 191.
} 
Parties undertake to recognise that every person belonging to a national minority has the right to display in his or her minority language signs, inscriptions and other information of a private nature visible to the public".

This broader approach convenes with my above proposal that group rights are all group related rights. One can distinguish among these rights by subject: collective rights as rights the beneficent subject/right-holder of which are groups; and individual rights, if the individual is concerned with respect to its membership, and also if the obliged subject is either the group or a state.

\subsection{Justification of Group Rights}

\subsubsection{Justification on the Basis of the Nature of the Group}

In a way of argumentation that resembles Otto von Gierkes Theory of the personality of associations ("Theorie der Verbandsperson") some authors try to justify collective group rights by referring to the identity of groups. Groups should not be considered a unity because they are granted rights from the legal order as legal persons, but on their own right, because of the social processes forming these groups. Groups are considered to be subjects of specific values, have independent organizations and strive for a certain form of autonomy. According to the theory of public goods, certain goods can only be obtained by groups and not by individuals. Joseph Raz claims that public goods serve the individual person in a non-competitive fashion. ${ }^{44} \mathrm{Such}$ goods are e.g. the environment, language and cultural heritage. Some of these goods can only be used collectively, others, such as fresh air, also individually. ${ }^{45}$ Since individual rights also protect individually enjoyable goods, collective rights can only be justified with reference to goods that cannot be consumed individually. Jovanovich assumes that air, culture, language and the environment fulfill this criterion in general. ${ }^{46}$ According to him, only exaggerated

\footnotetext{
44 Jovanovic 2012, p. 84

45 Jovanovic 2012, p. 87.

${ }^{46}$ Jovanovic 2012, p. 92: ,whether a good qualifies for the designation 'participatory' depends decisively on the meaning given to that good by the very people in question".
} 
individualism would base these goods on individual interests. ${ }^{47}$ Should an individual person make use of such a right, it would be only in the interest of the group itself. ${ }^{48}$

This approach faces two objections: First, the nature of a good does not predetermine the form of its guarantee or protection. As the Framework Convention shows, common goods or individual interests do not have to be protected by rights - be they individual or collective at all, but can be guaranteed by a mere objective state obligation. If the nature of a good as an objective value, would preclude it from being protected as an individual right, the objective dimension of these rights as objective values could not be explained. Finally, the factual question that their social identity is formed by traditions and social practices, does not presuppose their normative identity. This normative identity does not stem from extra-legal factors, but from the norms attributed to a certain entity. Accordingly, a group is a legal unity only as a legal person. And being a legal person is dependent on the attribution of rights to this group. Thus we have to distinguish the legal subjectivity of the group on the one hand and the extent of rights forming the legal identity of this group on the other. For the decision of the latter the question of values may be relevant, but not for the legal personality of the group. As Art. 19 III German Basic Law states, there may indeed be rights that are not applicable to legal persons as collective rights; but to assume that there are rights that do not ultimately serve the individual would be a one-sided collectivism, at least not a conception of collective rights the above mentioned declarations and charters purport.

\subsubsection{The Interest-Approach}

This is, however, more or less the assumption of the interest approach to rights Joseph Raz and Avishai Margalit defended in an earlier paper. They assume that there are interests, which cannot be reduced to individual interests. They would be related to the interests of group members, but are not identical with them: ,it does not follow that, if an American moon landing

\footnotetext{
47 Jovanovic 2012, p. 56: "It was demonstrated that collective entities could be said to exist independently of their individual members. This existence can, at times, be recognized as a specific good worthy of legal protection. Furthermore, it was shown that one might legitimately endorse the concept of collective interests as something substantially different from the aggregate sum of individual interests. Finally, it was elucidated that value individualism is a product of one specific historical era and, as such, cannot be absolutized, let alone taken as 'truth'. In that respect, one may even argue, contra the belief of adversaries of value collectivism, that this standpoint is 'counterintuitive', that there are many clear signs in the current global developments that value collectivism is endorsed intuitively, if not systematically, in our daily political and legal practice".

${ }^{48}$ Jovanovic 2012, p. 9: ,collective rights can be exercised in any of the three following ways: they can be exercised by the group itself (e.g. the right to self-determination); by some agent of the group (e.g. the minority right to participate in designing the curriculum in publicly funded schools, which will be exercised by some representative of the minority group); or by an individual member of the group (e.g. the right to address authorities in one's own language). What in all cases - including the last one - qualifies the right as collective is the fact that it ultimately serves the interests of the group as such, and not of individuals".
} 
increases the world's admiration for the United States, Americans necessarily benefit from this". ${ }^{49}$ However, Raz mainly has officers in the public sector in mind.

However, officers ideal-typically never have their personal interests in mind, as we know from Max Weber and others. Their duty is to promote public interests. This model does not fit for the members of benefitted groups, such as minority rights. They are not organs or agents of the groups as public legal persons.

\subsection{The Critique of Collective Group Rights}

Even international human rights documents, which contain group related rights are reluctant to proclaim collective rights. Most of them speak of the rights of individual persons belonging to a group, e.g. to a minority. However, beginning with the right to self-determination of peoples international declarations do contain rights of groups. And so far the possibility of them is neither proven nor rejected.

Some scholars deny the existence of collective rights as human rights altogether. For Donnelly, for example, it is like looking for a black cat in a dark room. ${ }^{50}$ Collective rights could not be based on human dignity as human rights can. ${ }^{51}$

One could also criticize that human rights are to protect individual human beings against states. Accordingly, states could not be subjects of human rights, because than they would have to be protected against themselves. However, this line of critique is erroneous. The freedom of association clearly is a human right. Some associations only make sense if they can defend themselves independent of their members. Therefore, they could have a collective right. Accordingly, if a state is in the situation that its collective rights (e.g. the right to development) are endangered by other states, as the individual is by states, and if these collective rights are expressions of the human rights of their members (i.e. they are their associations), then they can be the subject of human rights.

Some critics of group rights give them only instrumental function for the interests of individuals. Accordingly, collective rights could only be justified with respect to these

\footnotetext{
${ }^{49}$ Raz/Margalit 1990, pp. 449 f.: „Group interests cannot be reduced to individual interests. It makes sense to talk of a group's prospering or declining, of actions and policies as serving the group's interest or of harming it, without having to cash this in terms of individual interests. The group may flourish if its culture prospers, but this need not mean that the lot of its members or of anyone else has improved".

50 "A philosopher is a person who goes into a dark room on a moonless night to look for a nonexistent black cat. A theologian comes out claiming to have found the cat. A human rights lawyer, after such an on-site visit, sends a communication to the Commission on Human Rights; and a member of the Commission leaves the room drafting a resolution on the treatment of black cats. This, in a nutshell, is uncomfortably close to the history of the so-called human right to development". Donnelly 1985, S. 473.

${ }^{51}$ Donnelly 1985, p. 493: "To have a human right, one need be nothing other than a human being, nor do anything other than be born human. In the human rights tradition, the very fact that one is a human person entails the possession of basic rights; to be human is to have human rights... The third generation of solidarity rights simply are not, and logically cannot be, human rights-unless "human rights" is now to be taken to mean something other than it has always meant".
} 
individual interests. Janos Kis assumes that the ability of a group to be a subject of collective rights is justified, if the respective community has the same interest in the unfolding of a culture, as the individual member is interested in the development of this culture. ${ }^{52}$ This would mean, however, that they could correctly be called human rights. Based on his "Agency Approach", James Griffin holds that human rights are meant to secure the agency of human beings. Group rights would at best be justified if they served this goal. However, he sees no point in protecting them as rights at all, but instead suggests to give these interest a mere objective value as principles of justice, fairness or pursuit of happiness, not entitling groups or individuals to any claims. ${ }^{53}$ This assumption is too vague though and does not adequately describe the intended character of the international declarations, some of which indeed only establish obligations on the states, but others acknowledge legal claims of individuals and groups.

\section{The justification of group rights based on the legal form of these rights and their ethical content}

This leads to an approach that justifies to justify group rights by ethical considerations.

As mentioned before, following the hermeneutics of human rights declarations, I consider group rights as group related rights of either groups as such (collective group rights) or of individuals (individual group rights) if the right is directed either at the group itself or at states with regard to the group membership of the individual.

\subsection{The Legal Form of Group Rights}

Group rights are primarily individual rights. Rights are claims of a legal subject against another legal subject to a particular object. ${ }^{54}$ As such, rights are not mere objective principles or duties of states, but claims. Whoever a right is attributed to, is a subject of this right. Accordingly, a right can be attributed to an individual person, a group, but also to companies, foundations, associations etc. All become (natural or juridical) legal persons by the attribution of these rights. The privileged subject is the beneficiary, the obliged subject the addressee of the right. By attributing a right to someone or something, the law becomes subjective and the

\footnotetext{
${ }^{52}$ Kis 1995, S. 227: „We can say that a community has an interest in its preservation and the flourishing of its culture if it is also possible to say that the individuals making up the community have an interest in the preservation of their community and the flourishing of its culture. If there is no one who expects a benefit for herself from the existence of the community, then we cannot reasonably say that there are interests in the preservation of the community". Jovanovic bezeichnet diese Position als Aushöhlung der kollektiven Rechte, weil das Gemeinsame zu einer bloßen "facon de parler" verkomme, Jovanovic 2012, S. 52.

${ }^{53}$ Griffin 2011, S. 276; Donnelly 1985, p. 483: „,not everything that is good or desirable, nor even everything that is the goal of the enjoyment of a right, is itself a right".

${ }^{54}$ Robert Alexy, Theorie der Grundrechte, 3. Aufl. 1996, S. $171 \mathrm{ff}$.
} 
subject achieves an objective legal validity as a legal person. Thus, already in the form of an individual right, objectivity and subjectivity are basically mediated. ${ }^{55}$

Yet, not all of these rights are human rights. The question which criterion specifies an individual right as a human right is hotly debated. I cannot go into this here. ${ }^{56}$ Human rights specify the general structure of individual rights with respect to the beneficiary, the addressee and the obligation of the claim. The range of beneficiaries encompasses at minimum all human beings. The obligated addressee/duty-bearer of human rights depends on their form: If we consider their moral form, human rights may oblige all human beings and institutions, however, if we take them as legal rights - and we do here - they primarily oblige public authorities. ${ }^{57}$ The distinguishing feature between moral and legal rights is the latter's positivity through the recognition in international declarations and covenants or national constitutions. The legal form of human rights is called fundamental rights. The obligation of the claim of human rights concerns fundamental human values. What "fundamental" means is expressed by the preambles of the UN Charter or the UDHR. They express the idea that all human rights are based on the fundamental right of human dignity. All other human rights are concretizations of this basic human right to be permitted to make oneself the person one wants to be. Only if this right is respected, one is treated as a subject and not instrumentalized for other purposes. These further rights secure the unfolding of the personality of the human being by negative rights, not to be instrumentalized, positive rights to secure the unfolding in situations, in which the individual is incapable of realizing itself by itself and active rights in the participation in legal affairs that have legal effects on him.

So far the formal concept of human rights as individual rights does not provide arguments for or against the establishment of collective or individual group related rights as human rights.

\subsection{The Ethics of Group Rights}

Arguments could come from analyzing the content of human rights. The content refers to the expression "human" in human rights. By recognizing its ability to obtain human rights, the specific human dignity of a subject is acknowledged. This recognition and the legal recognition of the human dimension in all his life is indeed a fundamental legal interest that qualifies a right as a human right.

\footnotetext{
${ }^{55}$ Hegel's disciple Eduard Gans 1971, S. 74: „Die Person wird als das Subject von Rechten definiert, was sie unstreitig ist: aber daß sie noch etwas ganz Anderes sey, nämlich das Umgekehrte - das Recht als Subject, wird gewöhnlich in diesen Definitionen übersehen.“

${ }^{56}$ Kirste 2012, marginal no. 1

${ }^{57}$ Kirste 2012, marginal no. 13 f.,
} 
One might object that restricting human rights to the recognition of human dignity would be a very limited concept of both the legal obligations of human rights and of the beneficiaries of these rights. I cannot go into the details of the range of obligations here and want to mention only that human rights are necessary as far as they protect human dignity. Further aspects of his humanity may however justify other human rights.

In the remainder of this paper I want to concentrate on the benefitting subjects of such a conception of human rights. Or, more specific, can collective rights be justified on this basis or is the specification of "human" as the fundamental interest in human rights rather a predecision for a limitation of group related rights to individual rights? The answer does indeed depend on the concept of human that is to be applied with regard to human rights.

As shown above, the image of men in human rights declarations in international law is not one of an isolated individual self. Although the independence of the individual self is a goal of these declarations and charters, the individual human being develops in exchange with others and has to be recognized by others. ${ }^{58}$ On the one hand, beginning with the Universal Declaration of Human Rights, negative rights towards communities are protected; on the other hand, duties of men with regard to communities are mentioned (Art. 29 I). Both Covenants from 1966 adopt this principle and emphasize in their preambles ,that that the individual, having duties to other individuals and to the community to which he belongs". Hereby the Covenants express the idea that human beings as individuals shall be protected by human rights, develop in exchange with the communities, in which he lives, and again that these communities are shaped by the influences of their members. This does not mean that communities predetermine the possible identities of the individual in a communitarian sense, nor in a liberalist understanding that common values always and exclusively emerge from the actions of the individuals and only serve their individual interests. ${ }^{59}$ Rather both form each other in the historical process of exchange between the individual and the communities he lives in.

The above-sketched idea of the justification of the right to self-determination of peoples by individual human rights can be generalized for other group rights. Both the collectivist and the individualist position make the same mistake by taking groups and individuals as given entities. Therefore, they cannot build bridges between the two, but have to either dissolve the individual into a group or the group into individuals. In a strange way, ontological conceptions influence the justification of collective rights that seem to have been overcome a long time ago.

\footnotetext{
${ }^{58}$ An analysis of the image of men in human rights: Brugger 1999, p. $79 \mathrm{f}$.

${ }^{59}$ For different forms of communitarianism and also mediating concepts cf. Brugger 1999, pp. 74 ff.; Brugger 2013 , pp. 279 ff.; Lohmann 2013, pp. $148 \mathrm{f}$. and $159 \mathrm{f}$.
} 
The oft-quoted idea of Lord Jennings to the right to self-determination is symptomatic for this: "(O)n the surface it seemed reasonable: let the people decide. It was in fact ridiculous because the people cannot decide until someone decides who are the people"60

If one accepts this idea, the identity of a group could be determined from the outside. However, this would neglect the historicity of the group just as the assumption that a human being is only insofar a human being as he was created as such. Not just existentialism ${ }^{61}$, but already Pico della Mirandola has shown that men is a being that has to create himself the one he wants to be. ${ }^{62}$ Human beings are developing themselves; their historicity is their essence. This applies to groups as well. They are not fixed institutions to perpetuate inherited traditions, fixed religions and heritage-protected cultures, but build and form themselves through communicative processes. In any case, it is up to the group to decide if it intends to devote itself to the preservation of the past or to a perpetual development of its ideals.

It would certainly mean social romanticism to assume that this process is realized by all members in all groups. ${ }^{63}$ The establishment of a collective group right does at the same time increase the power of persons acting for these groups. ${ }^{64}$ This power can be carried out in an authoritarian fashion and can even be used as a means of suppression of the members of these groups. It can in particular infringe the use of the individual rights in these groups. Therefore, it is necessary for the individual person that his individual group rights are accompanied by individual human rights against groups and in particular rights that contain exit options. ${ }^{65}$ Art. 3 of the Framework Convention of the European Council gives "every person belonging to a national minority the right freely to choose to be treated or not to be treated as such and no disadvantage shall result from this choice or from the exercise of the rights which are connected to that choice". However, it does not provide the right to leave the group (negative membership right); the affiliation to the group is supposed to depend on objective criteria. ${ }^{66}$ Conversely, there may be interests of groups that have to be balanced with individual interests. ${ }^{67}$

\footnotetext{
${ }^{60}$ Jennings 1956 , p. 56.

${ }^{61}$ Sartre 1986, pp. 7-51, pp. $10 \mathrm{f}$.

${ }^{62}$ Pico della Mirandola, Oratio de Dignitate Homine.

${ }^{63}$ A danger Donnelly uses for his criticism against collective rights, Donnelly 1985, p. 498 f.

${ }^{64}$ Rittsteig 1996, p. 1001.

${ }^{65}$ Rittsteig 1996, S. 1001: „Gruppenrechte können mit dem Recht des Individuums kollidieren, nicht als Angehöriger einer Ethnizität behandelt zu werden und von Bindungen an ethnische Gemeinschaften frei zu sein“.

${ }^{66}$ The explanatory reads as follows:

"34. Paragraph 1 firstly guarantees to every person belonging to a national minority the freedom to choose to be treated or not to be treated as such. This provision leaves it to every such person to decide whether or not he or she wishes to come under the protection flowing from the principles of the framework Convention.

35. This paragraph does not imply a right for an individual to choose arbitrarily to belong to any national minority. The individual's subjective choice is inseparably linked to objective criteria relevant to the person's identity".

${ }^{67}$ Jovanovic 2012, p. 146: Auf der Basis seines „Wertkollektivismus“ nimmt Jovanovic an, daß es möglich ist, „to claim that some rights vested in groups qua groups can be of such a crucial importance as to allow of certain individual rights to be outweighed, even those of group members, and the concept of collective rights, which would automatically exclude the possibility that they can ever override the rights of individuals, would be, for all practical purposes, useless".
} 
In line with Hegel's idea of freedom as the driving force of history and the foundation of law one could assume that there are groups ${ }^{68}$ in which only one can freely decide about the identity of the group (like in theocratic groups). Other groups, where only very few can do so have an oligarchic structure. Finally, there are groups in which the identity of the group depends on the free self-determination of its members, which then participate in the development of the identity of this group. In a group of the last type, the validity of the identity building values of the group depends on the communicative process of the group itself. We are therefore permitted to assume that the realization of the communicative rights of this community is a necessary condition for the realization of the identity of this group. ${ }^{69}$ At the same time, from the perspective of the members the identity of the group is both the condition for the possibility of their communication and also the result of this communication. ${ }^{70}$ For example, language is not merely a fixed media for the individual member of a linguistic group, but develops by communicating. The individual members are not more dependent on the language of a group as a precondition of their communication as free communication of individuals influences language .

In this way, the rights of the group and the rights of the members of the group are dialectically interrelated, just as expressed in the commentary to Art. 27 ICCPR:

\begin{abstract}
Although the rights protected under article 27 are individual rights, they depend in turn on the ability of the minority group to maintain its culture, language or religion. Accordingly, positive measures by States may also be necessary to protect the identity of a minority and the rights of its members to enjoy and develop their culture and language and to practise their religion, in community with the other members of the group.
\end{abstract}

In the development of their selves, persons do not depend less on groups than groups depend in their development on the individual members. Their self-determinations are mutually dependent. Accordingly, even the classic example of collective group rights can thus be reconstructed from individual human rights, just as many individual human rights can be reconstructed as group related rights.

Based on these considerations the theoretical question of group rights can be answered such that a group can be a legal subject itself, namely a derivative subject of international law,

\footnotetext{
68 "The History of the world is none other than the progress of the consciousness of Freedom the Eastern nations knew only that one is free ; the Greek and Roman world only that some are free ; whilst we know that all men absolutely (man as man) are free", Hegel, Lectures on the Philosophy of History, 1914, p. 20.

${ }^{69}$ Boysen 2009, p. 447: „Die Fähigkeit zur Selbstbestimmung des politischen Status durch eine Volksgruppe setzt notwendig einen Rahmen individueller Bekenntnisfreiheit voraus, über die sich entsprechende Formen kollektiver Kommunikation und autonomer Zustimmungsbekundung entwickeln können“.

${ }^{70}$ General Comment No. 23: The Rights of Minorities (Art. 27), 4 August 1994, CCPR/C/ 21/Rev.1: "The right of self-determination is of particular importance because its realization is an essential condition for the effective guarantee and observance of individual human rights and for the promotion and strengthening of those rights".
} 
as far as rights can be attributed to the group. ${ }^{71}$ These group rights are human rights if and insofar as the group is an expression and a condition of the actions of its members. The answer to the moral question which rights should be collective group rights in general is that a group deserves the more rights the more its identity is developed by its members and the less the less this is the case. These rights are limited by the legitimate rights of the states, in which these groups exist, and in the human rights of their members and of third persons. ${ }^{72}$ These limitations can be stricter in democratic constitutional states than in other states that threaten both group rights and other human rights by the lack of recognition of the rule of law and other constitutional principles.

Understood in this dialectical way of the foundation and development of the identity of groups by the communication of their members on values and the realization of the grouprelated social attributes of the individual member by the group, collective group rights are candidates for the universalization of the idea of human rights. They have the potential to mediate rather collective Asian values with rather individualistic western conceptions of human rights.

\section{Literature}

Alexy, Robert (1998): Die Institutionalisierung der Menschenrechte im demokratischen Verfassungsstaat. In: Philosophie der Menschenrechte. Hrsg. v. Gosepath, Stefan; Lohmann, Georg. Frankfurt/Main 1998, S. 244-264.

Alexy, Robert (1996): Theorie der Grundrechte. 3. Aufl. Frankfurt/Main 1996.

Boysen, Sigrid (2009): Demokratische Selbstbestimmung? Zum Verhältnis von staatlicher Integrität und Gruppenrechten im Völkerrecht. In: Archiv des Völkerrechts, Bd. 47 (2009), S. 427-453.

Brugger, Winfried (1999): Das Menschenbild der Menschenrechte. In: Ders. Liberalismus, Pluralismus, Kommunitarismus. Studien zur Legitimation des Grundgesetzes. BadenBaden 1999, S. 74-86.

Brugger, Winfried (2013): Zur Rationalität des Kommunitarismus und zu seiner Bedeutung für die Verfassung Deutschlands und Europas. In: Winfried Brugger: Integration, Kommunikation, Konfrontation in Recht und Staat. Hrsg. v. Helen Brugger und Stephan Kirste. Berlin (Schriften zum Öffentlichen Recht Band 1252) 2013, S. 275-304.

Donnelly, Jack (1985): In Search of a Unicorn: The Jurisprudence and Politics of the Right to Development. In: California Western International Law Journal 15 (1985), S. 473-509.

\footnotetext{
${ }^{71}$ Apart from genuine subjects of international law, more and more persons and organizations (like NGOs) are being acknowledged as partially legally capable subjects. Heilbronner/Kau marginal no. $7 \mathrm{f}$.

${ }^{72}$ Boyen (2009, p. 445) holds it that „die Verwirklichung des Selbstbestimmungsrechts seine Grenzen nur in solchen Strukturen staatlicher Souveränität findet, die ihrerseits dem Grundsatz der Gleichberechtigung und Selbstbestimmung der Völker folgen“.
} 
European Council (Explanatory Report): Explanatory Report to the Framework Convention for the Protection of National Minorities.

http://conventions.coe.int/treaty/en/Reports/Html/157.htm, zuletzt aufgerufen am 15.10.2014.

Freeman, Michael (1995): Are there Collective Human Rights? In: Political Studies 43 (1995), S. 25-40.

Gans, Eduard: Naturrecht. Vorlesungsnachschrift - Winter 1828 bis Ostern 1829. In:

Philosophische Schriften. Hrsg. v. H. Schröder. Berlin 1971, pp. 37 - 154.

Gierke, Otto von (1902): Das Wesen der menschlichen Verbände. Berlin 1902.

Griffin, James (2011): On Human Rights. Oxford.

Heilbronner, Kay/Kau, Marcel (2010): Der Staat und der Einzelne als Völkerrechtssubjekte. In: Völkerrecht. Hrsg. v. W. Graf Vitzhum. 5. Aufl. Berlin 2010, S. 147-263.

Hilpold, Peter (2013): Das Selbstbestimmungsrecht der Völker. In: JuS 2013, S. 10811086.

Höffe, Otfried (1999): Demokratie im Zeitalter der Globalisierung. München 1999.

Jennings, Ivor (1956): The Approach to Self-Government. Corona 1956.

Jones, Peter: Group Rights and Group Oppression. In: The Journal of Political Philosophy 7 (1999) S. 353-377.

Jovanovic, Miodrag (2005): Recognizing Minority Identities through Collective Rights. In: Human Rights Quarterly 27 (2005), S. 625-651.

Jovanovic, Miodrag (2012): Collective Rights. A Legal Theory. Cambridge 2012.

Kirste, Stephan (2002): Die Realisierung von Gemeinwohl durch verselbständigte Verwaltungseinheiten. In: Gemeinwohl in Deutschland, Europa und der Welt. Hrsg. v. M. Anderheiden, W. Brugger und S. Kirste. Baden-Baden 2002, S. 327-390.

Kirste, Stephan (2012): § 204. Die naturrechtliche Idee überstaatlicher Menschenrechte. In: HbStR, Bd. 10. Hrsg. v. P. Kirchhof und J. Isensee. Heidelberg 2012, S. 1-30.

Kirste, Stephan (2012a): § 8. Föderalismus als Rechtskultur. In: Handbuch Föderalismus. Föderalismus als demokratische Rechtsordnung und Rechtskultur in Deutschland, Europa und der Welt. Band 1: Grundlagen des Föderalismus und der deutsche Bundesstaat. Hrsg. v. I. Härtel. Heidelberg u.a. 2012, S. 197-222.

Kirste, Stephan (2013): Das Fundament der Menschenrechte. In: Der Staat 2013, S. 119-138.

Kirste, Stephan (2013a): The Human Right to Democracy as the Capstone of Law. In: Human Rights, Democracy, Rule of Law and Contemporary Social Challenges in 
Complex Societies. Hrsg. v. B. A. Rocha, K. Salgado, M. C. Galuppo, M. Sette Lopes, Th. B. Silva dos Santos u. a. Belo Horizonte 2013, S. 103-120.

Kirste, Stephan (2014a): Die beiden Seiten der Maske - Rechtstheorie und Rechtsethik der Rechtsperson. In: Kirste, S./Gröschner, R./Lembcke, O. (Hrsg.): Person und Rechtsperson. Tübingen (Reihe Politika) 2014, 26 S. (im Erscheinen).

Kirste, Stephan (2014b): „Der Mensch ist das Maß der Dinge“ - Dimensionen rechtlicher Gerechtigkeit. In: Gerechtigkeit, Hrsg. v. G. Schweiger. Darmstadt (Europäische Grundwerte, Hrsg. v. C. Sedmak) 2014, S. 7-34.

Kirste, Stephan: Die Zeitlichkeit des positiven Rechts und die Geschichtlichkeit des Rechtsbewußtseins, Berlin (Schriften zur Rechtstheorie; H. 183) 1998.

Kirste, Stephan: Recht - Selbst - Bestimmung. Neuere Konzepte der Autonomie und ihr Verhältnis zum Recht. In: Würde und Autonomie. Hrsg. v. K. Seelmann u. D. Demko. Stuttgart 2014, S. 65-89 (im Erscheinen).

Kis, Janos (1995): Beyond the Nation State. In: Social Research 63 (1995), S. 191-245. Lohmann, Georg (2005): Die Menschenrechte: Unteilbar und gleichgewichtig? In: ders./S. Gosepath/A. Pollmann/C. Mahler/N. Weiß: Die Menschenrechte: Unteilbar und gleichgewichtig? Potsdam 2005, S. 5-20.

Lohmann, Georg (2013): Individuelle Menschenrechte und Pflichten zugunsten von Gemeinschaften. In: Philippe Brunozzi, Sarhan Dhouib, Walter Pfannkuche (Hg.): Transkulturalität der Menschenrechte: Arabische, chinesische und europäische Perspektiven (Welten der Philosophie) Freiburg-München 2013, S. 147-170.

Margalit, Avishai and Raz, Joseph (1995): National Self-Determination. In: Will Kymlicka (Hrsg.): The Rights of Minority Cultures. Oxford 1995, S. 81 ff.

Nussbaum, Martha (2007): Frontiers of Justice. Disability, Nationality, Species Membership. Cambridge/Mass. 2007.

Pogge, Thomas (1997): Group Rights and Ethnicity. In: Ian Shapiro and Will Kymlicka (eds.), Ethnicity and Group Rights. New York and London 1997, S. 257-289.

Rainer, Hans (1961): Selbstbestimmungsrecht und Demokratie. In: ARSP 47 (1961), S. 477502.

Raz, Joseph (1986): The Morality of Freedom. Oxford 1986.

Rittsteig, Helmut (1996): Blätter für Deutsche und Internationale Politik 41 (1996), S. 993 1004.

Sartre, Jean-Paul: Ist der Existenzialismus ein Humanismus? In: Drei Essays. Frankfurt am Main, Berlin 1986. 
UN Human Rights Committee (HRC): CCPR General Comment No. 23: Article 27 (Rights of Minorities), 8 April 1994, CCPR/C/21/Rev.1/Add.5, available at:

http://www.refworld.org/docid/453883fc0.html, last 14.05.2015.

Weiß, Norman (2012): Minderheitenschutz. In: Menschenrechte. Ein Interdisziplinäres Handbuch. Hrsg. v. A. Pollmann u. G. Lohmann. Stuttgart/Weimar 2012, S. 286-304. 